\title{
ON NOMINALIZING THE SERIAL VERB IN MABIA LANGUAGES
}

\author{
Adams Bodomo \\ Hasiyatu Abubakari \\ Dewei Che
}

\begin{abstract}
Verb serialization and nominalization are two prominent phenomena in descriptive and theoretical syntax. This paper raises a number of issues that result from the interaction between these two widely attested phenomena in the literature: nominalization (e.g. Chomsky 1970, Roeper 1993, Alexiadou 2011, Lieber 2016) and verb serialization (e.g. Foley and Olson 1985, Baker 1989, Bodomo 1993, Lord 1993, Collins 1997, Stewart 2001, Foley 2010, Haspelmath 2016). Based on data from Dagaare and Kusaal, two Mabia languages of West Africa, this paper analyses a serial verb construction which is a type of complex predicate construction in which all the verbs in a series are nominalized, with only one of the verbs carrying the nominalization affix (Bodomo and Oostendorp 1993, Bodomo 2004, Hiraiwa, Bodomo 2008, and Abubakari 2011). Such a rare complex predicate construction is then the basis for renewed questions about the nature of complex predicatehood, diathetic syntactic alternations, and lexical categorial differences involving nouns and verbs across languages. The paper proposes a syntactic representation of these nominalized serial verbal predicates in which the verbal predicates are basically interpreted as VPs headed by a nomP functional projection. Semantically, we propose that nominalized serial verbs, like their purely verbal counterparts, express a complex event. It is thus concluded that while verbal and nominal predicates obtain from the same minimal constructs, the difference between pure serial verbs and nominalized serial verbs is due to the fact that a semantic feature, [+nom], parallel to the syntactic functional projection, nomP, imposes nominal features on the whole complex. This analysis is extended to complex verbal constructions in English.
\end{abstract}

Keywords: Syntax, lexical semantics, complex verbal constructions, nominalization, serial verb constructions, Dagaare, Kusaal, English. 


\section{Introduction ${ }^{1}$}

This paper analyses a type of complex predicate construction in Dagaare and Kusaal (two members of the Mabia branch of the Niger-Congo language family, spoken in West Africa by about five million people) involving not only verb phrase (VP) phenomena but also noun phrase (NP) phenomena. Specifically, this concerns the nominalization of serial verbal predicates. We term this nominalized serial verbal predicates or even serial verb nominalization (SVN) (Bodomo and Oostendorp 1993). The construction in (1b) which is an example from Dagaare, serves as a first example of the phenomenon. As can be seen, the last of the verbs in the SVC in (1a), di 'eat' is nominalized and the object NP à tàngmà 'the shea fruits' is preposed.
a. déré
nà $z \grave{o}$
gàà
di
lá
$\stackrel{a}{\mathrm{DEF}}$
Dery FUT run go eat FOC DEF
'Dery will go and eat the shea fruits (by running)'
'Dery will go and eat the shea fruits (by running)'
b. à tàngmà zó gàà dílín
'The run go eating of the shea fruits' i.e.
Running there in order to eat the shea fruits
DEF shea fruit.PL run go eat-NOM

tàngmà

shea fruit.PL

In Kusaal, on the other hand, a prefix $\grave{a}$ - is introduced before $V_{1}$ which scopes over the entire complex structure by nominalizing all the verbs as illustrated in (2b).
(2) a. Bá dàà zõ kĩy dĩ tá'ámá
3PL PAST ran go eat shea fruits
'They run and went and ate shea fruits.'
b. à-zó-kiń-dí-tá' amá
NOM-ran-go-eat-shea fruit
'the act of running to go and eat shea fruit/running in order to go and eat shea fruits'

The non-trivial effect of these syntactic alternations is that the whole verbal construction is now a nominalized construction. The consequence of this alternation is that the original SVC, headed by a VP, is now headed by an NP or a determiner phrase (DP). The

\footnotetext{
${ }^{1}$ The following are among abbreviations that have been used throughout the paper for interlinear translations. Other abbreviations not listed here have been explained in situ:

1.SG. $=$ First person singular pronoun; $3 . \mathrm{SG}=$ Third person singular pronoun; $\mathrm{COMP}=$ Complementizer; $\mathrm{DEF}$ $=$ Definite article DEM $=$ Demonstrative item; DET $=$ Determiner; FOC $=$ Focus; FUT $=$ Future tense marker; IMP = Imperfective aspect; INTENS = Intensifier; LOC = Locative marker; NEG = Negative marker; NOM = Nominative case marker; OBJ = Object; $\mathrm{PAST}=$ Past tense marker; $\mathrm{PERF}=$ Perfective aspect PL $=$ Plural; SG $=$ Singular; SUBJ $=$ Subject.
} 
SVN construction is therefore an interface zone for VP and NP phenomena, bringing issues of serialization and nominalization in focus.

Even though nominalization and verb serialization are widely attested phenomena in the generative linguistic literature, there exists only a little published attempt at accounting for the interaction between the two grammatical phenomena (see Bodomo 2004). The Dagaare and Kusaal data presented here can be used for further debate and analysis on these syntactic and semantic phenomena across languages. Aspects of the data and analysis on Dagaare, in this work, are sourced from Bodomo (2004). The paper will focus more on issues of description than formalization.

The paper is organized as follows: First, since SVN partially involves NP phenomena, we give a brief presentation and representation of the facts of the Dagaare and the Kusaal NPs in section 1, mainly using the DP hypothesis. We look at the structure of Dagaare and Kusaal nominal phrases in section 2. In section 3, we present the SVN facts, and offer in section 4 a syntactic representation of SVNs in the DP hypothesis, along with LexicalFunctional Grammar (LFG)-type functional structures to capture certain syntactic alternations in the SVN. Section 5 concludes the paper.

\section{The Structure of the Nominal Phrase in Dagaare and Kusaal}

We begin this section of the paper with a discussion of the basic structure of the Dagaare and the Kusaal noun phrases, including information on earlier studies and a brief discussion about some issues of constituency in the noun phrase. The following sentences in (2) and (3) illustrate simple Dagaare and Kusaal noun phrases, along with some basic facts about grammatical categorial markings within the noun phrases in these languages.

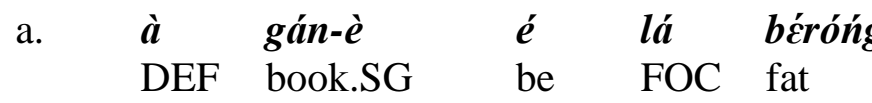

Dagaare

'The book is fat.'

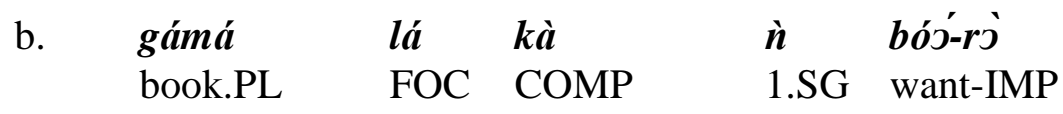

'It is books that I want.'

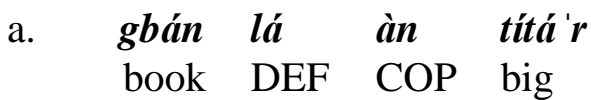

'The book is big.'

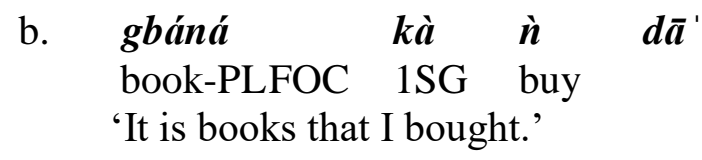

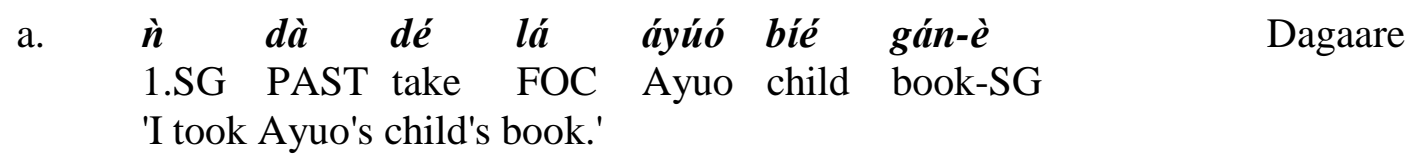




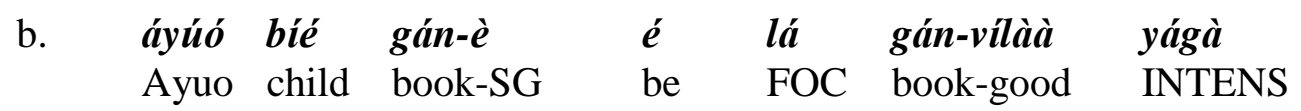

'Ayuo's child's book is a very good one.'

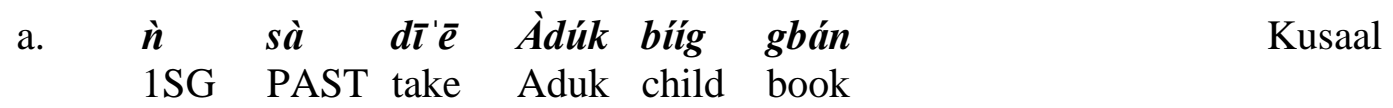
'I took Aduk's child book.'

b. Àdúk biíg gbán lá àn gbán-súm hálé Aduk child book DEF COP book-good INTENS 'Aduk's child boom is a good one.'

As can be seen in (3-4), the grammatical categories, number and definiteness are overtly marked and distinguished within the Dagaare and Kusaal noun phrases. The noun, gáne (Dagaare) and gbán (Kusaal) 'book' alternates between a singular and a plural form. Also, the definite form of this same noun is preceded by the definite marker, $\boldsymbol{a}$ in Dagaare while same is followed by the definite marker lá in Kusaal. However, the indefinite form does not have any such items marking it.

Case and gender, on the other hand, do not have overt markings within the Dagaare and Kusaal lexical noun phrases. This is illustrated in (5-6), where there is no morphological difference in the nominative/subjective and accusative/objective occurrences of the noun phrase, Ayúó bié gáne ('Ayuo's child's book' and Àdúk bíig gbán 'Aduk's child book in Dagaare and Kusaal respectively. Gender, as mentioned, is not also overtly marked, as there is no morphological difference between the nominative and genitive uses of the first person pronoun, $\boldsymbol{n}$, in both languages. Earlier studies of the nominal phrase in Dagaare, Kusaal and other related languages give us more substantial facts for understanding the nature of noun phrases and nominalization in Dagaare and Kusaal.

\subsection{Earlier Studies}

Earlier studies of the Dagaare noun phrase include Angkaaraba (1980), Bodomo (1993), Bodomo and Oostendorp (1993) and Bendor-Samuel (1971). The latter is a study of general Mabia NP, Mabia being the group of languages Dagaare and other Mabia languages belong to. Previous studies of NP/DP in Kusaal include Abubakari 2011; 2018)

a) Angkaaraba (1980)

Whereas Bendor-Samuel (1971) claims a very simple NP structure for Mabia languages, including Dagaare, for example suggesting that only one adjective could follow a head noun, the much richer possible structure of Dagaare NPs was clearly laid out in Angkaaraba (1980). The diagram below shows the complexity of the Dagaare noun phrase, according to Angkaaraba (1980): 
(7)

\begin{tabular}{|l|l|l|l|l|l|l|l|l|l|}
\hline 6 & 4 & 2 & 0 & 1 & 2 & & & & 3 \\
\hline & & & & & .2 & .4 & .6 & .8 & \\
\hline Art & $\mathrm{np}$ & $\mathrm{nm}$ & $\mathrm{NH}$ & $(\mathrm{pl})$ & Adj & Adj & Adj & Adj & $(\mathrm{pl})$ \\
\hline
\end{tabular}

\begin{tabular}{|l|l|l|l|l|l|}
\hline 4 & 6 & 7 & 8 & & 10 \\
\hline & & & .2 & .4 & \\
\hline Q & D & $(\mathrm{pl})$ & int & int & loc \\
\hline
\end{tabular}

Key: Art - Article; np - nominal phrase; nm- noun modifier; NH; Noun Head; pl - plural; Adj - Adjective; Q - Quantifier; D - Demonstrative; int - intensifier; loc - locative. Even numbers show slots where major constituents of the nominal phrase occur, while odd numbers indicate affixes of the preceding item.

According to the diagram, the head noun can be followed by adjectives, quantifiers, demonstratives, intensifiers, and locative markers. On the other hand, it can be preceded by modifiers, another noun phrase, and articles. Indeed, contrary to Bendor-Samuel (1971) which claims that Mabia languages never exhibit a string of adjectives after the head noun, this actually happens in Dagaare according to Angkaaraba (1980). The following construction illustrates this and all the other structures in the diagram:

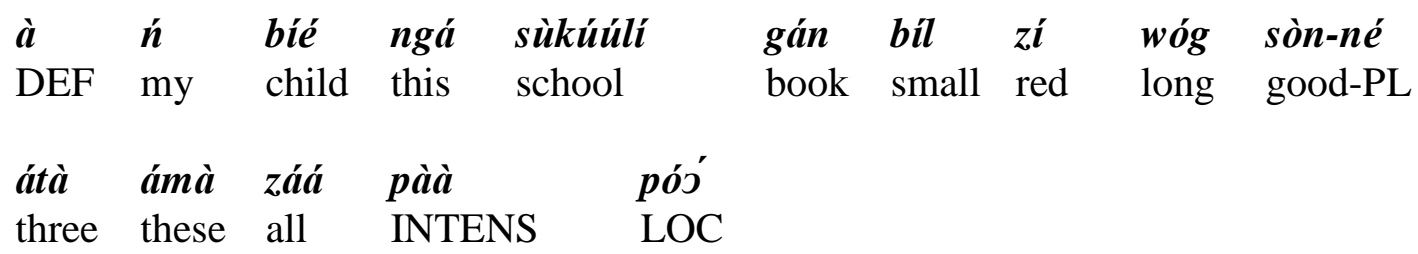

'Among all these three small red long good school books of this my child'

'Gán' is the head noun. It is followed by as many as four adjectives. 
b) Bodomo (1993)

This study builds on Angkaaraba (1980). While Angkaaraba (1980) sets only a maximum of four adjectives to follow the head, we can have more than that, as shown below.

$$
\begin{array}{llllllll}
\text { à } & \text { gán } & \text { bíl } & \text { zí } & \text { wóg } & \text { bàà } & \text { sòn-né } & \text { ná } \\
\text { DEF } & \text { book } & \text { small } & \text { red } & \text { long } & \text { slender } & \text { good-PL } & \text { those } \\
\text { 'Those small, red, long, slender, good books' } &
\end{array}
$$

c) Abubakari (2018)

This work observes that a series of adjectives can follow the head noun in a flexible order in Kusaal. Aside nationality which must precede the head noun, colour, shape, size, and quality can be reordered in a series of adjectival stacking in the language. Number can either be

\begin{tabular}{|c|c|c|c|}
\hline $\begin{array}{l}\text { gbáná } \\
\text { book-PL }\end{array}$ & $\begin{array}{l}\text { àtá }^{\prime} \\
\text { three }\end{array}$ & $\begin{array}{l}\text { títá 'dá sábilá } \\
\text { big-PL black-PL }\end{array}$ & $\begin{array}{l}\text { vénlá } \\
\text { nice-PL }\end{array}$ \\
\hline
\end{tabular}
marked on the last adjective in the series or on all the adjectives in the series but not on only the first or any medial adjective.

In effect, the argument about whether strings of adjectives can or can never follow a noun head in Mabia is partly also an argument about whether we consider nouns and adjectives to form one or more than one word. This issue may be clarified when we look at the following data in (11) from Dagaare, (12) from Mampruli and (13) from Kusaal respectively.

$\begin{array}{lll}\text { a. } \quad \text { yírí } & \text { 'house' } \\ \text { yíé } & \text { 'houses' } \\ \text { zéé } & \text { 'red' } \\ \text { kpóńg } & \text { 'big' }\end{array}$

but

b. $\quad y i ́$-zéé

house-red

'red house'

yí-zéé -ré

house-red-PL

'red houses' 
yí-zé-kpóńg

house-red-big

'red big house'

yí-zé-kpón-ní

house-red-big-PL

'red big houses'

Mampruli

(12) a. gbangngu 'book'

bila 'small'

gyia 'red'

but

b. gbang-bili-gyea

book-small-red

'small red book'

gbang-bili-gyee-se

book-small-red-PL

'small red books'

Kusaal
(13)
a.
$\begin{array}{ll}\text { bv́v́g } & \text { 'goat' } \\ \text { búvis } & \text { 'goats' }\end{array}$
bil 'small'
bílá 'small-PL'
zén 'ว́g̀ $\quad$ 'red'
zén 'ćd 'red-PL'
b. bó-bíl-ž́n 'j̀g
goat-small-red
'small red goat'
bó-bíl-zćn 'éd
goat-small-red-PL
'small red goats' 
In all three languages, as can be seen from the data, only the root form of the noun, thus the part without any inflectional suffix, is available when the noun takes on one or more adjectives.

Indeed, adjectives also lose part of their endings when they combine with a following adjective in which instance the noun and adjective(s) can be seen as forming one word. This observation is supported by the fact that the plural of the whole complex appears at the end of the last adjective in Dagaare while it may appear on all the series or only on the last adjective in Kusaal.

Looking at these constructions in Dagaare, Mampruli and Kusaal as single words would probably be the only way to defend the claim made by Bendor-Samuel (1971) that a noun (word) is never followed by a string of adjectives (as separate words) in Mabia. Even then the data do not dispute the fact that a noun or its stem is followed by adjectives or adjectival stems. This therefore shows that the data from these languages confirm the fact that the structure of the nominal phrase in Mabia is much more complex than observed by earlier works.

d) Bodomo and Oostendorp (1993)

This study even went further to show more complexities of the nominal phrase in terms of processes such as serial verb nominalization. Besides the descriptive advances, the study gave a formalization of the nominal phrase structure within the DP hypothesis of the GB grammatical framework.

The noun phrase has traditionally been described as that part of the sentence headed by the noun or pronoun. However, there are analyses within the linguistic literature (e.g. Hellan 1986, Abney 1987) that have challenged this conventional wisdom, arguing that the noun phrase is headed by the determiner, in which case then one would talk of the Determiner Phrase (DP). In this work we do not undertake an evaluation of which of the two approaches are better suited for nominal phrase formalization; we simply attempt to show how the DP approach can represent SVNs.

Abney (1987) argues that the determiner within the noun phrase should be analyzed as a functional head like other functional or non-lexical items such as INFL and COMP. In the same way that we have IP and CP in many languages of the world it is rational to have a DP cross-linguistically, according to this hypothesis. The DP is assumed to contain elements like determiners and demonstratives, and quantifiers. Quantifier phrase (QP) contains elements like numerals and other quantifier heads or phrases, as shown in (14).

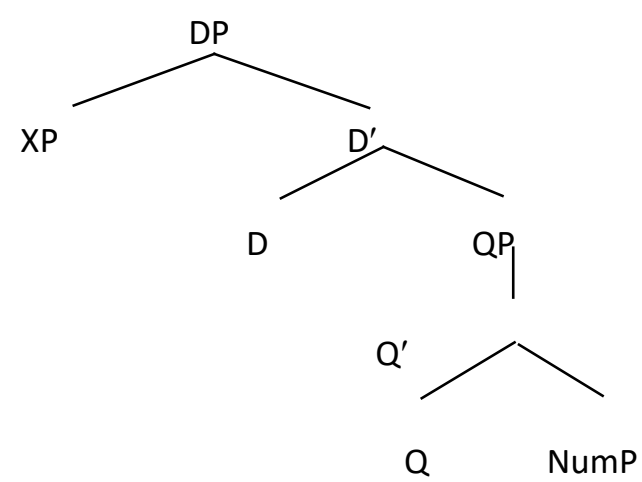


Now look at the Dagaare DPs in (15):

$(15)$
a. à ว́r-rè ámè áyì
DEF berry-PL DEM.PL two
'These two berries'
b. báyúó gán bìl- zì- wóg- bààl- sòn-né áyì Bayuo book small red long slender good-PL two 'Bayuo's two small, red, long, slender, good books.'

Apart from the determiner, $\dot{a}$, and possessive phrases, all elements in these phrases follow the head noun. Tentatively, we may conclude that this means that, except for DP, all projections in the Dagaare nominal phrase are head final. We thus get the structures in (16b) and (16c) for (15a) and (15b) respectively (some of the irrelevant intermediary structure is omitted):

(16) a.

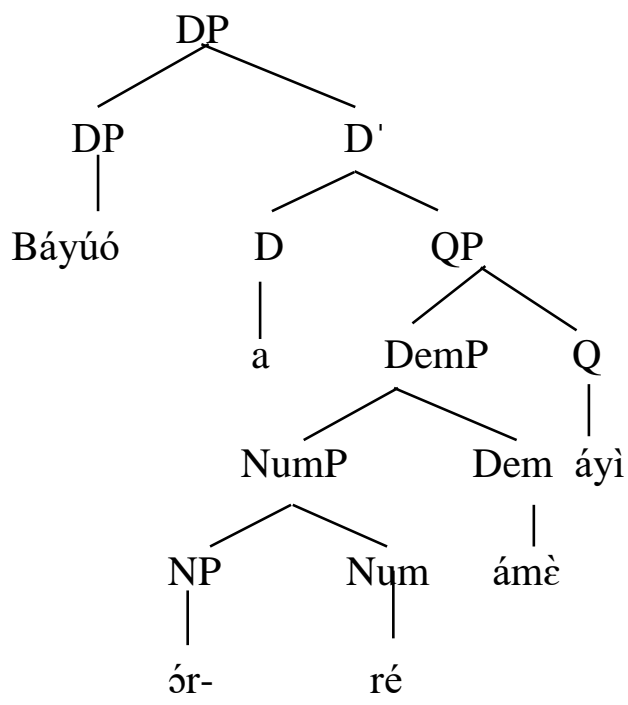


b.

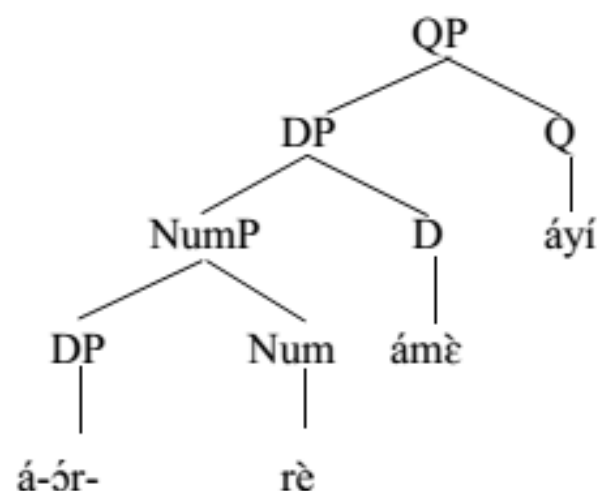

c.

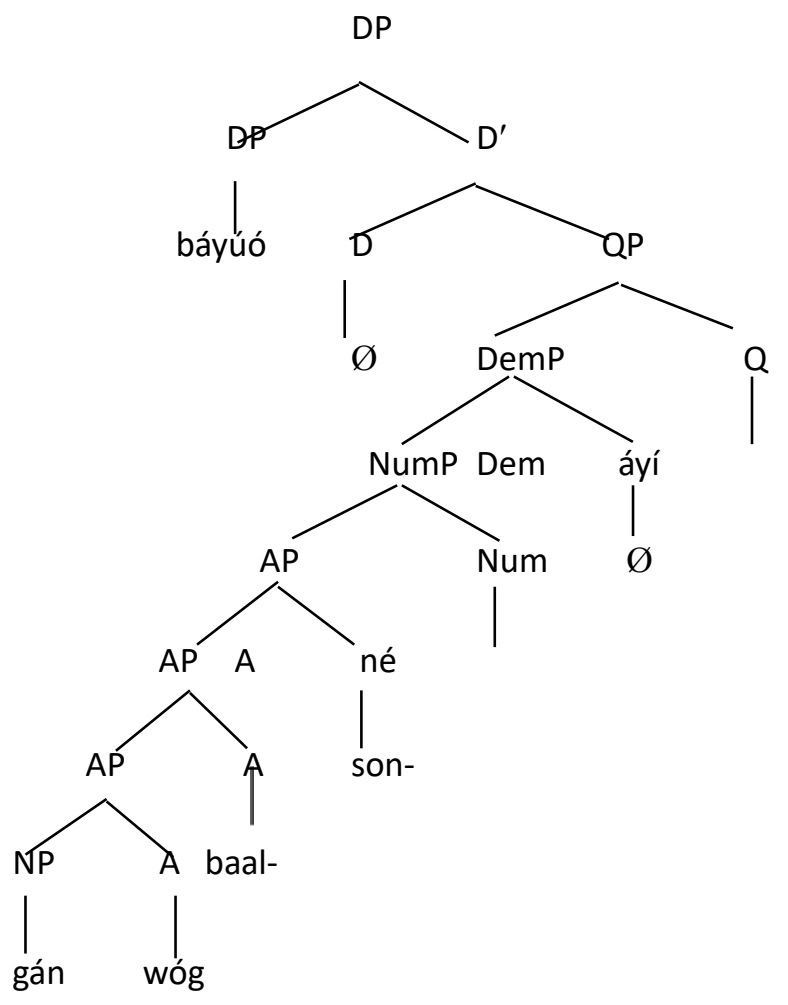


Contrary to what we claimed above, the demonstratives and determiners have been given their own projections here. This is not a matter of necessity. We could also assume a structure as in (16c). In this structure all nominal functional projections are right-headed. The determiner $a$ behaves as a clitic, coindexed with $\mathrm{D}^{0}{ }^{2}{ }^{2}$

e) Abubakari (2011): The Derivation of the DP in Kusaal

Abubakari (2011:12) shows that the DP in Kusaal is strictly head final on the surface: (Poss) N Adj Num Dem (Q). It is only the quantifier that occurs after the demonstrative or determiner as the case may be. Within the NP, the head noun, apart from cases involving the possessor, is the initial element with all modifiers occurring as postnominal elements. The postnominal elements in Kusaal correspond to one of the orders allowed by Greenberg's (1963) Universal 20. It will be assumed following the work of Cinque (2005:318) that the word order of the DP in this language is derived by movement of the NP. The NP is assumed to undergo successive movement to the specifier position of its dominating node and piedpiping the entire category that dominates it to the next Spec. This continues successively until the desired order is derived. The structure below is used as an illustration following Cinque (2005:318).

(17) a. Múfá gbáná títá 'dá ànú lá
Mufa book-PL big-PL five

\footnotetext{
${ }^{2}$ Regarding the representation of A's as heads in (16b), our attention has been drawn to the idea that in most DP analyses As are represented as complements and not as heads. We will like to believe, however, that the Dagaare data seem to justify the representation of As as heads. In any case, some studies treat adjectives as heads [of AGR] in a French construction like: La fille intelligente 'The intelligent girl.'
} 


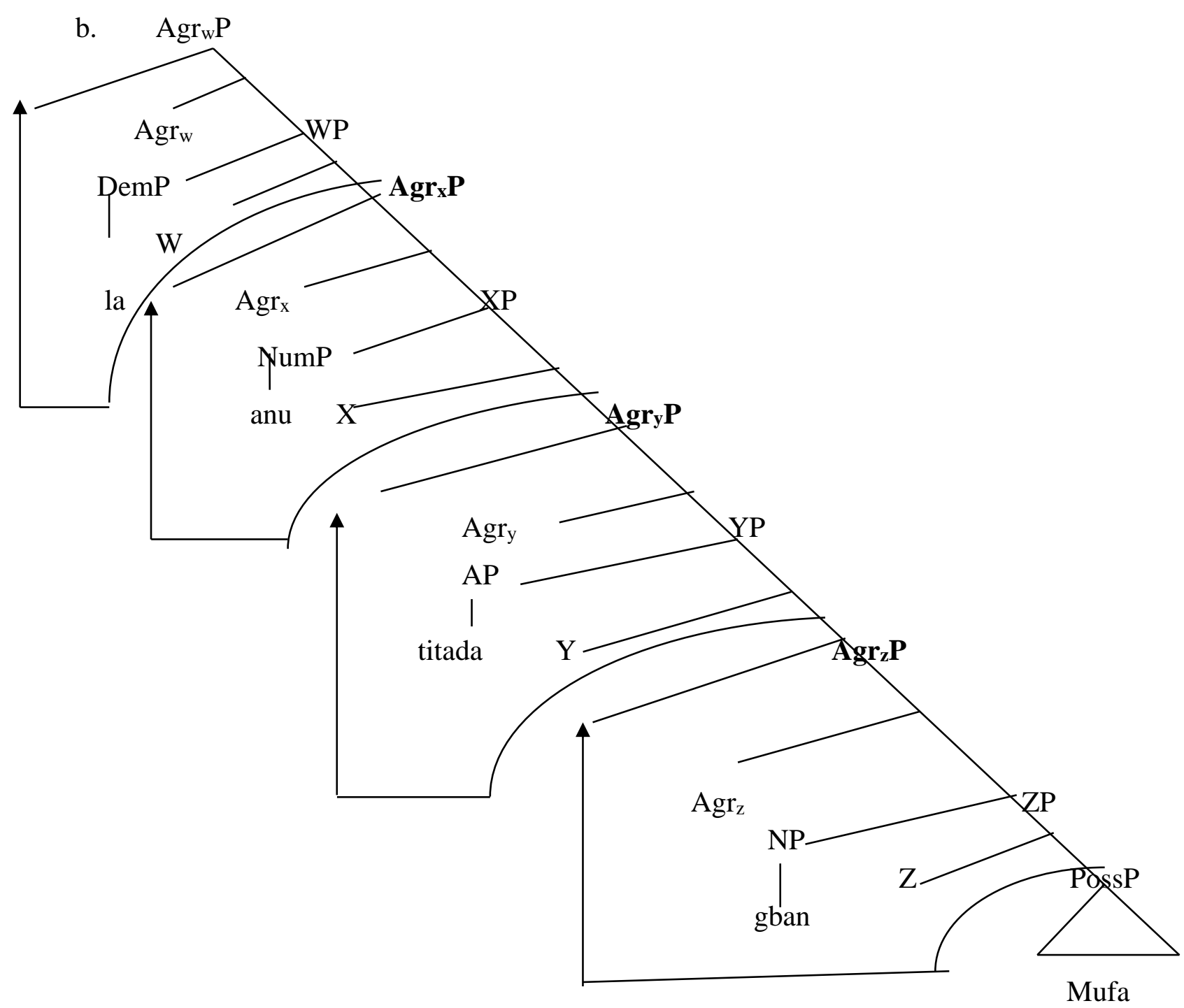

PossP ' $M u f a$ ' moves to Spec $\operatorname{Agr}_{\mathrm{z}} \mathrm{P}$ to derive 'Mufa gban'. $\operatorname{Agr}_{\mathrm{Z}} \mathrm{P}$ moves to Spec $\mathrm{Agr}_{\mathrm{y}} \mathrm{P}$ to derive 'Mufa gban titada'. The entire Agr $\mathrm{P}$ ' $M u f a$ gban titada' also moves to $\mathrm{Spec}^{\mathrm{Agr}} \mathrm{P}$ to form 'Mufa gban titada anu' Then $\operatorname{Agr}_{\mathrm{x}} \mathrm{P}$ also moves to $\mathrm{Spec} \mathrm{Agr}_{\mathrm{w}} \mathrm{P}$ deriving the order 'Mufa gban titada anu la' "Mufa's five big books". This derivation corresponds to the order Poss N A Num Dem. 
Having now given a survey of earlier treatments of the Dagaare and the Kusaal nominal phrases and a short representation of this in the DP framework, we shall in the next subsection state the facts of nominalization in both languages.

\subsection{Nominalization in Dagaare and Kusaal}

Nominalization is a process which involves the formation of nouns from verbs and adjectives. The following table shows how a number of verbs and adjectives are nominalized in Dagaare and Kusaal:

a. Verb

$\begin{array}{ll}\text { zó } & \text { 'run' } \\ \text { wá } & \text { 'come' } \\ \text { t’' } & \text { 'touch' } \\ \text { ngmé } & \text { 'beat' } \\ \text { zéé } & \text { 'swoop' } \\ \text { gbé } & \text { 'grind roughly' } \\ \text { gàà } & \text { 'go' } \\ \text { só’ } & \text { 'darken' }\end{array}$

b.
Nominalized item Dagaare

zóóú/zóóbú 'the act of running'

wááó/ wáábó 'the act of coming, arrival'

tóวó/tó ’́bó 'the act of touching'

ngméźbó/ngméźbó 'beating'

zééó/zéćbó 'the act of swooping'

gbíébú 'grinding roughly'

gààó/gààbó 'going/departure'

sóวó/sób́bó 'darkening'

Verb
kūā 'farm, weed'
kūa'ān 'brew'
nwē' $\boldsymbol{\varepsilon}$ 'beat'
kūōs 'sell'
nū (kuom) 'drink (water)
dī-pú 'á 'marry (woman)'

Nominalized item

kúób 'the act of farming/weeding'

kúán' áb 'the act of brewing'

nwé ' $\mathbf{c} \mathbf{b}$ 'the act of beating'

kúósím 'trading/ items for sale'

kuomnuudim 'the act of drinking water'

pú 'á-díré 'act of getting married (by a man)

Nominalization rule:

The following are examples of morpho-phonological derivational (i.e. word class changing) rules in Dagaare and Kusaal. These rules operate on a word to form another which belongs to a different word class (specifically the rules change verb forms to nominal forms):

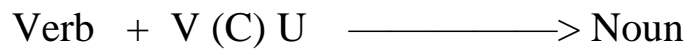

(A V (standing for any vowel) may be lengthened or diphtongised; if the vowel of verb is already long or diphtongised, no further lengthening or diphtongization is required; $\mathrm{U}$ (standing for high, back vowel) is unspecified for Advanced Tongue Root (ATR): it takes the ATR of source word) 
(20)

a. Adjective Nominalized item

Dagaare

$\begin{array}{llll}\text { fáá } & \text { 'bad' } & \text { fààlóǹg } & \text { 'bad deed, evil' } \\ \text { vèlàà } & \text { 'good' } & \begin{array}{l}\text { vèlòng } \\ \text { pèċlóng }\end{array} & \text { 'goodness, beauty' } \\ \text { pèlàá } & \text { 'while' } & \text { kphiteness' } \\ \text { kpóǹng } & \text { 'big' } & \text { kónnúng } & \text { 'bigness, seniority' } \\ \text { wógì } & \text { 'long, tall' } & \text { wógrúng } & \text { 'length, height' } \\ \text { sógláá } & \text { 'black, dark' } & \text { sjoglóng } & \text { 'blackness, darkness' } \\ \text { ngmàà } & \text { 'short' } & \text { ngmààlóǹg } & \text { 'shortness' }\end{array}$

b. Adjective + LUN<smiles>C1C[123I]N1</smiles>

( $\mathrm{L}$ is meant to be any liquid but note that if the adjective ends in a nasal the derivation involves a nasal gemination rather than L. Again, $U$ is unspecified for ATR: it takes the ATR of vocalic items in the source word.)

$\begin{array}{ll}\text { a. Adjective } & \text { Nominalized item } \\ \text {-píél } & \text { 'white' } \\ \text {-píl-píl } & \text { 'bright/clean' } \\ \text {-gólá } & \text { 'high' } \\ \text {-wá' ám } & \text { 'long/tall' } \\ \text { pój́d } & \text { 'small (quantity)' } \\ \text { búk } & \text { 'weak/tired' } \\ \text {-sún } & \text { 'good' } \\ \text { géćnm } & \text { 'mad' } \\ \text { gèn } & \text { 'tired/weak' } \\ \text {-tỏjg } & \text { 'bitter' } \\ \text {-túvólóg } & \text { 'hot' }\end{array}$

\begin{tabular}{|c|c|}
\hline $\begin{array}{l}\text { Kusaal } \\
\text { píélím }\end{array}$ & 'whiteness' \\
\hline pílím & 'brightness' \\
\hline gól & 'height' \\
\hline wá'álím & 'height' \\
\hline póódím & 'smallness' \\
\hline búgúsúm & 'weakness' \\
\hline sú'v́m & 'goodness' \\
\hline géenmis & 'madness' \\
\hline gèčlís & 'weakness' \\
\hline tว̈jg & 'bitterness' \\
\hline túvólúg & 'heat' \\
\hline
\end{tabular}

b. Adjective $+\mathrm{Vm} / \mathrm{s}$, or Adjective $+\emptyset \longrightarrow$ Noun

The adjective usually takes a suffix which is often in the form of a vowel plus the nasal $/ \mathrm{m} /$ or the consonant $/ \mathrm{s} /$. There are instances where the root form, thus the adjective, still serves as the nominal form.

With these data and rules showing how verbs and adjectives are nominalized, ${ }^{3}$ we now state the facts of nominalizing the simple VP in Dagaare to give us more extended NPs.

\footnotetext{
${ }^{3}$ There are other nominalization processes such as the formation of agentive nouns with the suffix -ráá (or any liquid and/or a V related to the $\mathrm{V}$ of the stem) 'doer' put on the imperfective form of the verb (with various vowel and tone changes) e.g. kó 'farm' $\rightarrow$ kúórò 'farming' $\rightarrow$ kúóráá 'farmer'; yó 'roam' $\rightarrow$ yúórò 'roaming,
} 
A verb like $\boldsymbol{d} \boldsymbol{i}$ ' 'eat' can be nominalized by marking it with the ending -(í) $\boldsymbol{u}$. If it appears, the direct object stands to the left of the head in these constructions. Compare (22a) to (22b), for example.
báyj̀̀ dì-ré
dì-ré
lá à
tànǵgmà
Bayor eat-IMP FOC DEF
shea fruit.PL

'Bayor is eating the shea fruits'
b.

$\begin{array}{lllll}\grave{a} & \text { tàn'gmà } & \text { dí-íú } & \text { wá } & \text { báárè } \\ \text { DEF } & \text { shea fruits } & \text { eat-NOM } & \text { NEG } & \text { finish.PERF }\end{array}$

'The eating of the shea fruits is not finished'

The verb $n \boldsymbol{w} \boldsymbol{\varepsilon}$ ' $\boldsymbol{\varepsilon}$ 'to beat', in Kusaal, is nominalized by adding the consonant $/ \mathrm{b} /$ as illustrated in (23b) below.
a. $\quad b \grave{a} \quad n w \bar{\varepsilon} ' \bar{\varepsilon} d \quad g o ́ o ́ g i^{4}$
3PL play.IMPERF googi/music
'They are playing googi'
b. góógí lá $n w \bar{\varepsilon} ' \bar{\varepsilon} b \quad$ pò bás
googi DEF play-NOM NEG stop
'The playing of the googi has not stopped.'

The construction in (22b) is introduced by the definite article $a$ in Dagaare while the head noun has the article lá after it in (23b) for Kusaal. Instead of this, we could also have an NP in the position of this determiner (22a) or a pronoun as in (23b). This NP would then denote the agent of the action. Finally, the position can also be left empty, as in (24b) from Dagaare and (25b) from Kusaal respectively.
a. báyúó tàngmà
dí-íú
véźlé lá
Bayuo shea fruit.PL eat-NOM
good FOC
'Bayuo's eating of shea fruits is good'
b. tàńgmà dí-íú nòmó lá
shea fruits eat-NOM sweet FOC
'Eating shea fruits is nice'

roving' $\rightarrow$ yóóráá 'roamer/rover, tourist'; zó ‘run' $\rightarrow$ zòró 'running' $\rightarrow$ zóró 'runner, athlete'. Dakubu (1996) also reports that the related language, Gurune nominalizes verbs by giving the verb roots nominal suffixes.

${ }^{4}$ Local name for a type of music as well as the instrument used for playing that music. 
(25) a. Àdúk góógì $n w \bar{\varepsilon} ' \bar{\varepsilon} b \quad$ málís

Aduk googi play-NOM sweet

'Aduk's playing of googi is nice.'

b. Góógì $n w \bar{\varepsilon} \bar{\varepsilon} b \quad$ málís

googi play.NOM nice

'Playing of googi is nice.'

Báyúó or Àdúk in $(26 \mathrm{a}, \mathrm{b})$ in this position could be a genitive or it could be a nominative. We cannot tell because the languages lack overt case markings.

a. báyúó gáné wá véélé

Bayuo book.SG NEG good

Dagaare

'Bayuo's book is not good'

b. Àdúkgbán káí sóm

Aduk book NEG good

Kusaal

'Aduk's book is not good.'

The direct object can be a bare noun like in $(24 b, 25 b)$, but it can also be an NP of more complexity (27b-c, 28b-c):

$(27)$
a. óràà dí-íú
nòmó lá
berry eat-NOM
sweet FOC
'Eating a berry is nice'
b. à j̀ràà nyè dí-íú nòmó lá
DEF berry DEM. SG eat-NOM sweet FOC
'The eating of this berry is nice'
c. á jòré ámè áyì dí-íú nòmó lá
DEF berry-PL DEM.PL two eat-NOM sweet FOC
'Eating these two berries is nice'

(28) a. Góógì $n w \bar{\varepsilon} ' \bar{\varepsilon} b \quad$ málís

googi play.NOM nice

'Playing of googi is nice.'

b. Góógì lá $n w \bar{\varepsilon} ' \bar{\varepsilon} b \quad$ málís

googi DEF play.NOM nice

'Playing of the googi is nice.' 


\section{c. Góógì àyí nwá $n w \bar{\varepsilon} ' \bar{\varepsilon} b \quad$ málís googi two these play.NOM nice 'Playing of these two googi is nice.'}

The resulting structure can be modified by an adjective - which is incorporated into the head as in (29a) or by an adverb as in (29b). The variant with the adverb is far more common, however.

\section{a. $\quad \grave{a}$ tàńgmà dí-vèc̀lòng}

DEF shea fruit.PL eat-good/nice

'The good eating of the shea fruits' i.e.

The nice way of eating the shea fruits

\section{b. à tàńgmà vèlàà dí-íú}

DEF shea fruit.PL good eat-NOM

'The good eating of the shea fruits' i.e.

The nice way of eating the shea fruits

These are then some of the facts of nominalizing the simple VP in Dagaare and Kusaal. In the next section we shall focus on the more complex case of nominalizing the serial verbal predicates.

\section{The Facts of Serial Verb Nominalization}

In nominalizing serial verb constructions in Dagaare, the last of the series of verbs gets the nominalized suffix. If there is a direct object to the last verb, it can only occur at the outer left of the verbal cluster:

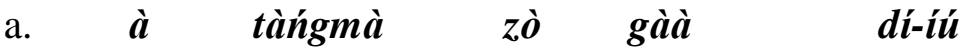
DEF shea fruit.PL run go eat-NOM
'The run go eating of the shea fruits ' i.e.
'Running there in order to eat the shea fruits'
b. * à zò gàà à tàńgmà dí-íú 


\section{c. * à zó à tàńgmà gàà dí-íú}

Not just the direct object NP, but also other constituents appear obligatorily to the left of the verbal cluster. This is the case with adverbials such as wiéwié 'quickly' as can be seen in (32).
a.
à tàngmà wiéwié $\quad z \grave{o} \quad g a \grave{a}$ dí-íú
DEF shea fruit.PL quickly run go eat-NOM
'The run go eating of the shea fruits quickly' i.e.
'Running there quickly in order to eat the shea fruits'

\section{b. * à wiéwié zó gàà tàngmà dí-íú \\ c. * à wiéwié zó tàngmà gàà dí-íú}

It seems that for one reason or another, the verbs have to be obligatorily adjacent in these constructions. This is a first indication by the facts of SVN in support of our theoretical analysis of serial verb constructions as complex predicates which undergo syntactic operations as a single unit. It is impossible to use the imperfective aspect in these constructions; they all seem to be in the perfective aspect or lack aspectual marking altogether:
a. $\quad * \grave{a}$
tàngmà
$z \grave{o}-\boldsymbol{r o ́} \quad g \grave{\varepsilon}-r \varepsilon ́$
dí-íu
$\mathrm{DEF}$
shea fruit.PL
run-IMP go-IMP
eat-NOM
$\begin{array}{cccc}\text { b. } & * \text { à } & \text { néǹ } & \text { dúg-rì } \\ \text { DEF } & \text { meat } & \text { boil-IMP }\end{array}$
ว́ó-ó
chew-NOM

Perhaps we can conclude that the nominalized form is inherently in the perfective aspect or that, since the whole construction is now nominal, aspect is not even marked at all. Tense can also not be expressed in nominalized constructions. Compare the sentences in (34) with the nominalized constructions in (35):
a. à bié ná zó gàà dí lá à tàngmà DEF child FUT run go eat FOC DEF shea fruit.PL 'The child will run there (and) eat the shea fruits'
b. à bíé dà zó gàà dí lá á tàngmà DEF child PAST run go eat FOC DEF shea fruit.PL 'The child has run there and eaten the shea fruits.'


(35)

\begin{tabular}{|c|c|c|c|c|c|}
\hline $\begin{array}{l}* \grave{a} \\
\quad \mathrm{DEF}\end{array}$ & $\begin{array}{l}\text { tàńgmà } \\
\text { shea fruits }\end{array}$ & $\begin{array}{l}n \boldsymbol{n} \dot{ } \\
\text { FUT }\end{array}$ & $\begin{array}{l}z \boldsymbol{o} \\
\text { run }\end{array}$ & $\begin{array}{l}\text { gàà } \\
\text { go }\end{array}$ & $\begin{array}{l}\text { dí-íú } \\
\text { eat-NOM }\end{array}$ \\
\hline $\begin{array}{l}* \grave{\boldsymbol{a}} \\
\mathrm{DEF}\end{array}$ & $\begin{array}{l}\text { tànǵgmà } \\
\text { shea fruits }\end{array}$ & $\begin{array}{l}\boldsymbol{d} \grave{a} \\
\text { PAST }\end{array}$ & $\begin{array}{l}z \dot{o} \\
\text { run }\end{array}$ & $\begin{array}{l}\text { gàà } \\
\text { go }\end{array}$ & $\begin{array}{l}\text { dí-íú } \\
\text { eat-NOM }\end{array}$ \\
\hline
\end{tabular}

Another characteristic feature of these SVN constructions in Dagaare is that it is difficult to get an acceptable reading when two NP objects are involved. This is the case with instrumental SVCs. An example of instrumental serialization is provided in (36a).
a. ó dà dé lá sòj ngmàà nén ó
3.SG PAST take FOC knife cut meat chew
'S/he cut meat with a knife and ate it.'

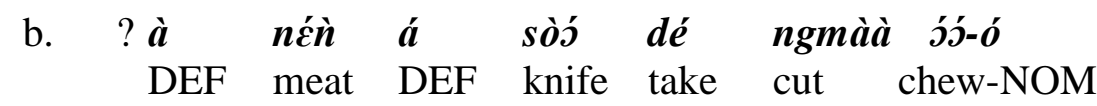
$\begin{array}{lllllll}\text { c. } & \text { ?? à } & \text { néǹ } & \text { dé } & \text { á } & \text { sòó } & \text { ngmàà óó-ó } \\ & \text { DEF } & \text { meat } & \text { take } & \text { DEF } & \text { knife } & \text { cut chew-NOM }\end{array}$
d. *à sòj dé néǹ ngmàà óó-ó
DEF knife take meat cut chew-NOM

As can be seen in (36b-d) there are acceptability problems when we try to nominalize the SVC in (36a). These constructions were discussed at length on various occasions with four other native speakers (two men and two women). All five agreed on (36d) as ungrammatical, while we were divided about the grammaticality status of ( $36 \mathrm{~b}$ and c). The construction in (36b) was generally said to be better than (36c) but the general agreement was that both (36b and c) are quirky and do not look very natural Dagaare sentences. We may therefore speculate at this point that SVN is more naturally derived from the objectsharing type of serial verb constructions. It is probably no sheer coincidence that it is these types of SVCs which seem to behave more as a unit under various syntactic alternations.

Situations involving the preposing of an object and the internal nominalization of a verb in SVCs in Kusaal are not immediately clear compared to the form and structure the phenomenon takes in Dagaare where the object is pre-posed and the last verb gets nominalized. The following seem quite unnatural to speakers though further research is required to ascertain their ungrammaticality. 
(37)

a. Bà dàa dāa níg $k \bar{u} \bar{o} s^{5}$

3PL PAST buy cattle sell

'They bought cattle and sold them.'

b. ??níig $d \bar{a}^{\prime} \quad k \bar{u} \overline{o s i m}$

cattle buy sell.NOM

'Buying cattle in order to sell.'

What is commonly attested in SVCs in Kusaal is cleftting the verb to the left and nominalizing it whilst a copy remains at the original position (Abubakari 2011, 2015).

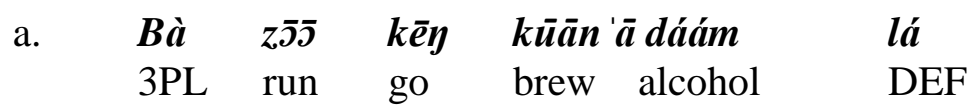

'They ran and went and brewed the alcohol.'

b. Dáám lá kūān'āb kà bà $z \bar{j} \bar{y} \quad k \bar{e} y \quad k \bar{u} \bar{a} n$ 'a acohol DEF brew FOC 3PL run go brew

'It is brewing the alcohol that they ran there and did.'

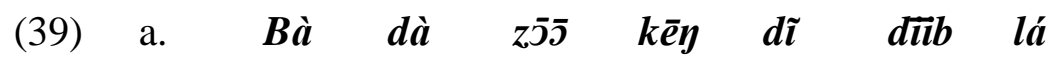

3PL PAST ran go eat food DEF

'They run and went and ate the food.'

b. zójg $\quad k \grave{a} \quad b \grave{a} \quad d \grave{a} \quad z \tilde{j} \quad k \bar{e} y \quad d \tilde{i}$ díb lá ran.NOM FOC 3PL PAST ran go eat food DEF

'It was running they did and went and ate the food.'

In addition, Kusaasi speakers predominantly create names out of (verb) phrases by prefixing the supposed phrases with the morpheme $\grave{a}$ - as illustrated in (40):

a. $\quad \grave{a}$-dá 'á-níígi

NOM-buy-cattle

'(Mr) cattle buyer',

b. à-mí-wús-dím

NOM-know-all-owners

'know all'

\footnotetext{
${ }^{5}$ The perfective aspectual form is, here, marked using zero morpheme.
} 


\section{c. à-pí-níy-yéddá \\ NOM-NEG-put-trust \\ 'Mr Have no Faith'}

The interpretation derived by the use of the prefix in this form is often seen as offensive by some speakers. Similarly, the same prefix can also result in an interpretation

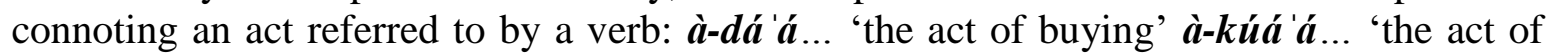
brewing' àdúg... 'the act of cooking'. Using the prefix in SVCs creates a complex structure where the entire series of verbs as well as arguments, if any, are combined for usually a single interpretation. This interpretation is mostly connected to an agent who is involved in the act referred to by the series of verbs or a meaning connoting the act of carrying the complex actions as a single event. The $\mathrm{V}_{1}$ in the SVC is commonly prefixed with the $\grave{a}$ - morpheme and all subsequent verbs are intuitively believed to be affected by the same interpretation. In effect, internal nominalization of SVCs in Kusaal is inherently realized on all the verbs in the series represented by the prefix on $\mathrm{V}_{1}$.

a. Bà $\quad \boldsymbol{k} \bar{u} a n^{\prime}$ dáám $\quad \boldsymbol{k} \bar{u} \bar{o} \mathbf{s}^{6}$

3PL brew alcohol sell

'They brewed alcohol and sold it.'

b. à-kúa'á-dáám-kúós

NOM-brew-alcohol-sell

'The act of brewing alcohol for sale.'

(42) a. Àdúk dá'á níg kúós

Aduk buy cattle sell

'Aduk bought cattle and sold them.'

b. à-dá 'á-nílg-kúós

'The act of buying and selling cattle/trading in cattle'

'A cattle trader'

Ayípókdúg díb kúós
Ayipok cook food sell
'Ayipok cooked food and sold it.'

b. à-dúg-díib-kúós

6 The perfective aspectual form is, here, marked using zero morpheme. 
'Cooking for sale/trading in cooked food.

'Mr cook food for sale'

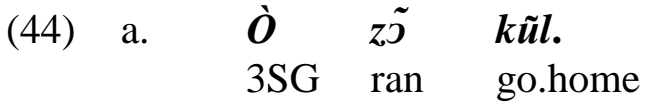

'He run and went home.'

b. à-zó-kúl

NOM-ran-go.home

'The act of running and going home (e.g. a recalcitrant pupil/worker)'

It is important to add that the series of verbs and any internal argument if present remain at their canonical positions with a nominal interpretation assigned to the predicates.

a. *Dáám-à-kúá á-kúós

alcohol-NOM-brew-sell

b. *Díib-à-dúg-kúós

food-NOM-cook-sell

Further evidence of the ungrammaticality of preposing the object whilst nominalizing the verb internally in Kusaal, is observed from the ungrammaticality of the instrumental SVCs below. These examples are renditions of the Dagaare data in (36) into Kusaal.

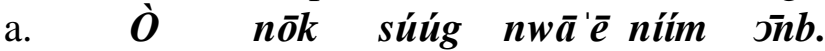

3SG take knife cut meat chew

'She took knife and cut meat and ate it.'

b. *Ním lá súúg nōk nwā'e jobim

meat DEF knife take cut chew-NOM

c. *ním lá nōk súúg nwā'e jobim

meat DEF take knife cut chew-NOM

d. *súúg lá nōk niím nwā'e jobim

knife DEF take meat cut chew-NOM

Again, unlike $\mathrm{V}_{1}$, all other verbs in the series cannot take the prefix $\grave{a}$ - in the event of nominalizing the entire complex predicate construction. 
(47)

a. *à-dá 'á-nílg-à-kúós

Nom-buy-cattle-NOM-sell

'The act of buying and selling cattle/trading in cattle'

'A cattle trader'

b. * dá 'á-níig-à-kúós

buy-cattle-NOM-sell

'The act of buying and selling cattle/trading in cattle'

'A cattle trader'

c. *à̀-zó-à- kúl

NOM-ran-NOM-go.home

'The act of running and going home (e.g. a recalcitrant pupil/worker)'

d. *zo-a-kul

ran-NON-go.hom

'The act of running and going home (e.g. a recalcitrant pupil/worker)'

\section{A Syntactic Representation for Serial Verb Nominalization}

Having documented SVN facts in the last section, we now turn our attention to a brief syntactic representation and analysis of these facts, first in Lexical-Functional Grammar (LFG)-type functional structures, and then in DP-type phrase structures. Since Dagaare and Kusaal present different structures in nominalizing the series of verbs in an SVN, we will limit our analysis of the phenomenon to Dagaare for the sake of space.

Recent versions of LFG show clearly that this grammatical framework belongs to a family of formal grammars that are increasingly developing a grammatical architecture of parallel structures in correspondence (Sadock 1991, Jackendoff 1997, Bodomo 1997, Bresnan 2001, Falk 2001, Dalrymple 2001, Kroeger 2004, and Bresnan et al. 2015), where rather than one level of representation being derived from another, all levels are independent of each other but only interface through rules of correspondence.

This alternative architecture of grammar is based on parallel structures, three of which include a-(rgument) structure, f-(unctional) structure and c-(onstituent) structure. These belong to the syntactic component and so far are the most developed. These are illustrated below in (48):

(48) a. a-structure:

$$
\begin{gathered}
\mathrm{R}<\underset{\mathrm{q} 1}{\mathrm{q} 1} \ldots \ldots \ldots \mathrm{qn}> \\
[\mathrm{fl}] \ldots \ldots . \mathrm{fn}]
\end{gathered}
$$

b. f-structure:

$\left[\begin{array}{ll}\text { PRED } & {[\ldots]} \\ \text { SUBJ } & {[\ldots]} \\ \text { OBJ } & {[\ldots]}\end{array}\right]$


c. c-structure:

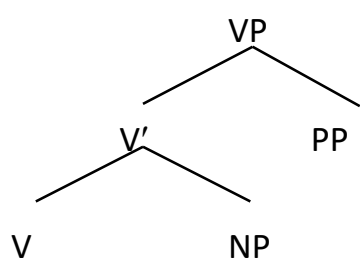

Bresnan (2001:20) explains these levels of representation as follows:

Each structure models a different dimension of grammatical substance: role, function, and category. Roles correspond to the grammatically expressible participants of eventualities (modelled by a-structure), syntactic functions belong to the abstract system of relators of roles to expressions (modelled by f-structure), and phrase structure categories belong to the overt structure of forms of expression (modelled by c-structure). The structures are associated by principles of functional correspondence (also called "linking" or "mapping" principles).

The relevant levels as far as the present paper is concerned are the f-structure and the c-structure, and it is SVN representations at these levels that we briefly illustrate in the next sub-sections.

\subsection{Functional Structure of SVNs}

Here, we provide LFG-type f-structure representations of this type of phenomena. ${ }^{7}$ The construction in (49) is the example of SVN to illustrate the various f-structure phenomena of this type of construction.
a. à tàngmà
DEF shea fruits go run eat-NOM
zò
gàà
dí-íu
'The run go eating of the shea fruits' i.e.
'Running there in order to eat the shea fruits.'

\footnotetext{
${ }^{7}$ In this framework, it is in the f-structure that grammatical functions, such as Subject, Object, etc. are stated. They are not defined in terms of phrase structure configurations. These grammatical functions are thus hardly reducible to phrase structure configurations which mostly vary from language to language.
} 
b.

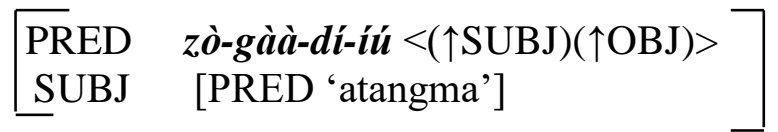

The f-structure in (49b) is a straightforward representation of SVN. As can be seen, the three verbs, $\boldsymbol{z o}$ 'run' gàà 'go' and the nominalized form of dí 'eat' - díú 'eating' together form a complex predicate, PRED, which is now monadic, as shown by the one argument slot (detransitivization seems to occur with nominalization). This slot is filled by the SUBJECT functional argument.

Evidence that the NP à tàngmà 'the shea fruits' becomes the subject of the whole nominalized construction can be adduced from pronominalization in the language. Even though we observed in examples (3-6) above that lexical NPs in Dagaare and Kusaal do not mark case, this does happen with the first person singular pronominal argument in Dagaare. The first person object/accusative pronoun of a normal SVC, which gets nominalized into an SVN, takes the form of nominative/subjective pronoun at the outer left of the whole construction. This is evidence for the fact that the lexical NP of SVCs which gets nominalized becomes the subject of the whole nominalized construction. We will illustrate this argument with the following sentences in (50), also see Abubakari $(2011,2015)$ for similar observation in Kusaal.

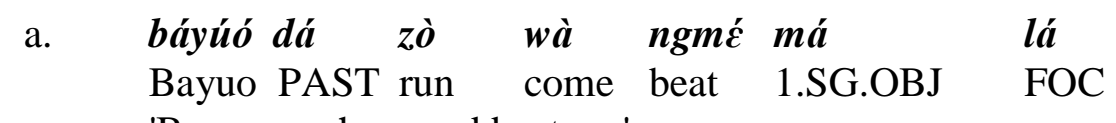
'Bayuo ran here and beat me'
b. $\quad * \grave{a}$ má zò wà $\quad$ nǵméć-ó DEF 1.SG.OBJ run come beat-NOM Bayuo's coming here to beat me.'

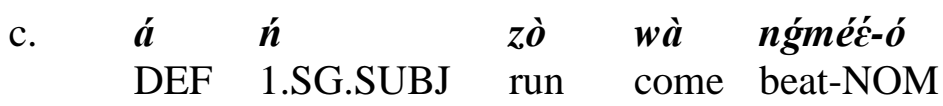
Bayuo's coming here to beat me' (Lit: The run coming here to beat me.)

The construction in (50b) is ungrammatical because the pronoun contains an objective pronoun case form, $\boldsymbol{m} \boldsymbol{a}$ ' 'me'. However, when its subject pronoun case form, $\boldsymbol{n}$ 'I', 'my', is used in this position, as is the case in (50c), the sentence is grammatical. It seems then that the diathetic alternation involving argument NPs in nominalized complex verbal predicates in Dagaare is one of object - subject alternation.

There seems to be only slight differences between the f-structure of nominalized serial verbal constructions and their purely verbal counterparts. This is illustrated in (51). 
$(51)$

a. báyúó dà zó gàà dí lá à tàńgmà Bayuo PAST run go eat FOC DEF shea fruits 'Bayuo went and ate shea fruits by running.'

b. $\quad\left[\begin{array}{ll}\text { PRED } & \boldsymbol{z} \text { ò-gàà }-\boldsymbol{d i ̀}<(\uparrow S U B J)(\uparrow \mathrm{OBJ})> \\ \text { SUBJ } & {[\text { PRED 'báyúó'] }} \\ \text { OBJ } & {[\text { PRED 'à tàńgmà ' }} \\ \text { TENSE } & \text { PAST }\end{array}\right]$

c. báyúó tàngmà zò gàà dí-íú

Bayuo shea fruits run go eat-NOM

'The run go eating of the shea fruits by Bayuo' or

'The run go eating of Bayuo's shea fruits by someone else.'

d.

\begin{tabular}{|c|c|}
\hline PRED & $z \grave{o}-\boldsymbol{g} \grave{a} \grave{a}-\boldsymbol{d} \boldsymbol{i}-\boldsymbol{i} \boldsymbol{u} \boldsymbol{u}<(\uparrow \mathrm{SUBJ})(\uparrow \mathrm{OBJ})>$ \\
\hline SUBJ & [PRED 'báyúó'] \\
\hline OBJ & [PRED 'à tàńgmà \\
\hline TENSE & PAST \\
\hline
\end{tabular}

e. $\quad \begin{aligned} & \text { PRED } \\ & \text { SUBJ }\end{aligned}$

zò-gàà-dí-íú $<(\uparrow S U B J)>$

[PRED 'báyúótàńgmà']

The construction in (51c) is a nominalized version of the SVC in (51a). This SVN is ambiguous, having two readings depending on whether Bayuo is seen as being agentive or simply a possessor. As observed above in several places, such as the examples in (3) and (5), Dagaare lacks case marking on lexical nouns, thereby making it impossible to read off a nominal or genitive case. This ambiguity is easily disentangled with the different $\mathrm{f}$-structures in (51d and e) with báyú ó being an agentive SUBJECT on its own in the former and a genitive within the SUBJECT in the latter.

\subsection{Phrase Structure Representation: A DP Analysis of SVNs}

Having discussed the f-structure representation of SVNs in the foregoing subsection, we now focus on a representation of these phenomena at the c-structure level of our parallel grammatical architecture. In terms of X-bar phenomena we shall attempt to extend the DP approach introduced in section 1 to the representation of SVN.

We now turn back to the nominalization facts. We have already seen that the nominalized forms can be modified by an attributive adjective as well. We assume a nominalization is a VP with a nominal functional projection set on top of it. Some of these functional heads are never realized for semantic reasons. For instance, because 
nominalizations cannot occur in the plural (cf (52a) for English and (53b) for Dagaare) we also cannot quantify them (cf (52b) for English and (53c) for Dagaare).

a. * Johns readings these books

b. * after three readings these books
a.

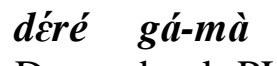
ám
sór-ò̀
Dery book-PL
DEM.PL
read-NOM
'Dery's reading of these books'
b. * déré gá-mà ámè sór-rè
Dery books these reading-PL
c. $* \grave{a}$

\section{gá-mà}
DEF book-PL
ám $\quad$ sór-rè
DEM.PL reading-PL three

Focusing now on nominalization, Abney (1987) has proposed that English nominalization constructions have the following structure:

(54)

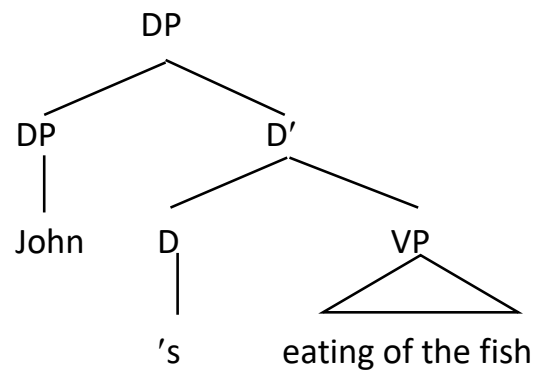

In this view, the nominal gerund constitutes a determiner which exceptionally takes a verbal projection as its complement, instead of a nominal projection. Following this proposal and Bodomo and Oostendorp (1993), we assume that an SVN is a VP with a nominal functional projection set on top of it. This is shown in (55).

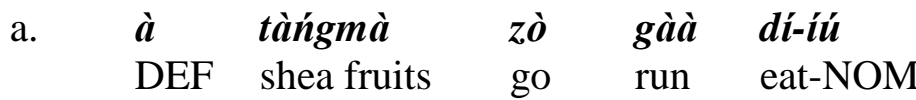
'The run go eating of the shea fruits' i.e.
'Running there in order to eat the shea fruits.' 
b.

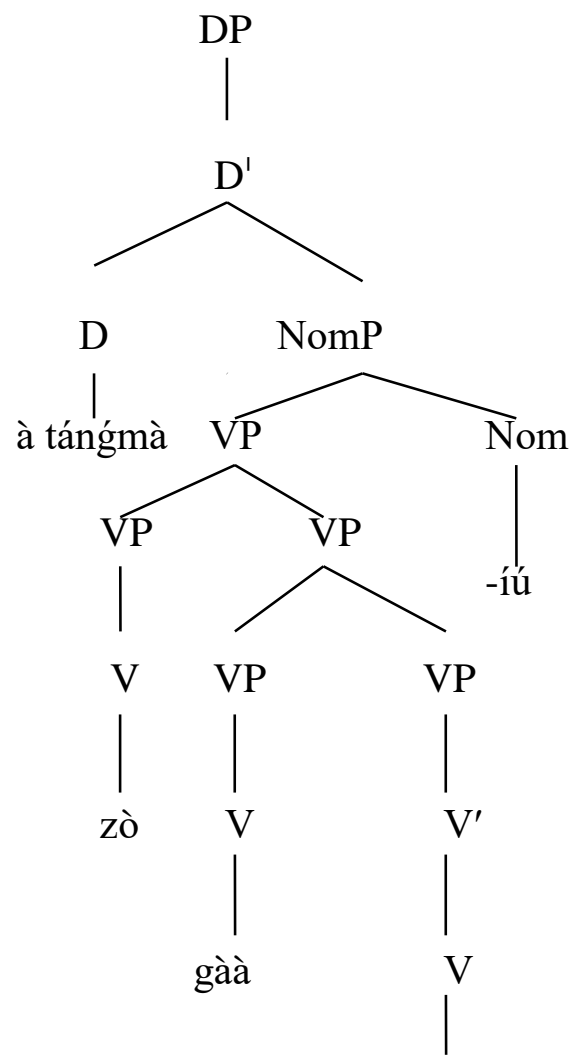

dí

As may be seen in this diagram, we represent Serial Verb Constructions (SVCs) as a succession of VPs with each subsequent VP adjoined to the other. This is different from the object sharing structures in Baker (1989) where an object in the SVC may stand as a complement of two lexical Vs. The obvious question would then be how objects are expressed in this configuration. This is an issue that has been discussed at length in Bodomo (1993, 1997). In this kind of configuration, as indeed in many of Baker's (1989) configurations, objecthood does not always need to be expressed configurationally as the sister of $\mathrm{V}$. Basically, the idea of expressing objecthood in such a configuration is to say that objects of the first $\mathrm{V}$ are expressed as sisters of $\mathrm{V}$ but that objects of subsequent Vs are expressed as referring back to the objects of the first V. If an NP occurs as a sister of a subsequent $\mathrm{V}$ and is not co-referential with the object of the first $\mathrm{V}$, the sentence would be ungrammatical.

With this representation we can now predict/explain quite a number of issues concerning the syntax of SVN such as why there is no tense, aspect or other functional categories normally associated with VP. To license the presence of tense for instance, there must be a TP (tense projection). But TP is normally located outside of the VP. However, as 
can be seen in the above diagram, the NomP projects on top of VP, i.e. where a TP would have been. There is thus no position for TP outside of the VP. The NP, à tàngmàn, can now also move to the beginning of the nominal complex (leaving the verbs adjacent to each other) since it is the subject of the whole construction. Evidence that it is the subject of the construction has already been adduced with the facts of diathetic alternation involving pronouns in (50).

We now bring this representation of the syntax of nominalized complex verbal construction in Dagaare to a close by drawing attention to one of the many possible crosslinguistic generalizations that the analysis seems to capture. This concerns the fact that predicate and functional items, as distinct from arguments, of nominalized complex constructions seem to cluster across languages. Chomsky (1970), for instance, observed the following contrast for (American) English:

(56) a. He looks the information up.

b. He looks up the information.

(57) a. * The looking of the information up (is difficult).

b. The looking up of the information (is difficult).

Hoekstra (1986) observes a similar contrast for Dutch:
a. Hij zoekt de
informatie
op.
he looks the
information up.

b.

...dat hij de informatie op zoekt.
that he the information up looks.
'...that he looks up the information.'

'...that he looks up the information.'

$\begin{array}{cllll}\text { a. } & * \text { Het } & \text { zoeken van de } & \text { informatie op (is moeilijk). } \\ \text { the looking of } & \text { the information } & \text { up (is difficult). }\end{array}$

b. Het op zoeken van de informatie (is moeilijk).

the up looking of the information (is difficult).

Just as in Dagaare where the predicate verbal items cluster in a nominalization, in both English and Dutch, as illustrated in (58) and (59), the predicate verbal items 'look'/'looking' and 'up' for English and 'zoekt'/'zoeken' and 'op' for Dutch do not have to cluster in the non-nominalized constructions but must cluster in the nominalized versions for the construction to be grammatical in each language. These, therefore, seem to be quite relevant cross-linguistic evidence in support of the Dagaare analysis we have presented in the paper. 


\section{Summary and Conclusion}

This paper has presented a discussion of the syntax of a rare kind of complex predicate construction, the Serial Verb Nominalization (SVN) in Dagaare and Kusaal, two Mabia languages spoken in West Africa. Following a presentation of the relevant facts of the Dagaare and the Kusaal NPs and SVNs, we proposed a syntactic representation of SVNs in the DP hypothesis, in the spirit of Bodomo and Oostendorp (1993), along with some LFGtype functional structures of these nominalized complex predicate constructions for the data from Dagaare. Basically, SVNs are VPs headed by a NomP functional projection. The construction was analysed as a nominalized complex predicate, given the fact that verbs tend to form a complex unit in various syntactic operations.

Given all these findings, we may therefore conclude that cross-linguistically, both nominal(ized) constructions and their verbal counterparts obtain from the same minimal configurations. The only difference between them is that a functional projection, NomP which is nominal in nature, influences the construction and cancels out some inherently verbal categories, such as tense and aspect, from the configuration. 


\section{References}

Abney, S. 1987. The English noun phrase in its nominal aspect. Doctoral dissertation, MIT.

Abubakari, H. 2018. Aspects of Kusaal Grammar: The Syntax-Information

Structure Interface. PhD Disseration. African Studies Department: University

of Vienna.

Abubakar, H. 2015. "Predicate cleft constructions in Kusaal". Paper presented at the International Workshop in Honor of Lars Hellan. African Studies Department, University of Vienna.

Abubakar, H. 2011. Object-Sharing as Symmetric Sharing: Predicate Clefting and Serial Verb Constructions in Kusaal. (M.Phil. Thesis, University of Tromsø,

Alexiadou, A. 2011. Statives and nominalization. Recherches Linguistiques de Vincennes 40, 25-52.

Angkaaraba, J. 1980. The nominal phrase in Dagaari. Long Essay, Department of Linguistics, University of Ghana, Accra.

Baker, M. 1989. "Object sharing and projection in serial verb constructions". Linguistic Inquiry 20, 513-553.

Bendor-Samuel, J. T. 1971. "Niger-Congo, Gur". In Current trends in Linguistics, edited by T. Sebeok. The Hague: Mouton.

Bodomo, A. 2004. "The syntax of Nominalized complex verbal predicates in Dagaare". Studia Linquistica, 58 (1): 1-22.

Bodomo, A. B. 1993. "Complex predicates and event structure: an integrated analysis of serial verb constructions in the Mabia languages of West Africa". Working Papers in Linguistics 20. Department of Linguistics, University of Trondheim, Norway.

Bodomo, A. B. 1997. Paths and pathfinders: exploring the syntax and semantics of complex verbal predicates in Dagaare and other languages, Doctoral dissertation, The Norwegian University of Science and Technology. Trondheim, Norway.

Bodomo, A. B. and M. Van Oostendorp. 1993. "Serial verb nominalisation in Dagaare". Paper read at the 24th Annual Conference on African Linguistics, Columbus, Ohio, USA.

Bresnan, J. (ed.). 1982. The Mental Representation of Grammatical Relations. Cambridge, MA: MIT Press.

Bresnan, J., A. Asudeh, I. Toivonen and S. Wechsler. 2015. Lexical Functional Syntax. 2nd edition. Wiley Blackwell.

Bresnan, J. 2001. Lexical-Functional Syntax. Oxford: Blackwell.

Chomsky, N. 1970. "Remarks on nominalization". In English transformational grammar, edited by Jacobs and Rosenbaum, 184 - 221.

Cinque, G. 2005. "Deriving Greenberg's Universal 20 and Its Exceptions". In Linguistic Inquiry, 36 (3). Cambridge, Massachusetts: MIT Press. 
Dakubu, M. E. K. 1996. A Grammar of Gurene. Corrected Trial Edition. Language Centre, University of Ghana, Legon, Accra.

Dalrymple, M. 2001. Lexical Functional Grammar. Syntax and Semantics, vol. 23. New York: Academic Press.

Falk, Y. N. 2001. Lexical-Functional Grammar: an introduction to parallel constraint-based syntax. Stanford, CA: CSLI Publications.

Foley, W. A. 2010. "Events and serial verb constructions". In Complex Predicates: Crosslinguistic Perspectives on Event Structure, edited by Mengistu Amberber, Brett J. Baker and Mark Harvey, 79-109. Cambridge \& New York: Cambridge University Press.

Foley, W.A. And M. Olson. 1985. "Clausehood and verb serialization”. In Grammar Inside and Outside the Clause: Some Approaches to Theory from the Field, Edited by Johanna Nichols and Anthony C. Woodbury. Cambridge \& New York: Cambridge University Press.

Greenberg, J. 1963. "Some universals of grammar with particular reference to the order of meaningful elements". In Universals of language, edited by Micheal Kefer and Johan van der Auwera, 105-118. (Belgian Journal of Linguistics 4.) Brussels: Edition de l'Université de Bruxelles.

Hellan, L. 1986. "The headedness of the NP in Norwegian". In Features and projections, edited by P. Muysken and Henk van Riemsdijk. Dordrecht: Foris Publications.

Hoekstra, T. 1986. "Deverbalization and inheritance". Linguistics 24, 549 - 584.

Jackendoff, R. 1997. The architecture of the language faculty. Cambridge, MA: MIT Press.

Kroeger, P. R. 2004. Analyzing Syntax: A Lexical-Functional Approach. Cambridge: Cambridge University Press.

Lieber, R. 2016. English nouns: The ecology of nominalization. Cambridge: Cambridge University Press, 2016.

Lord, C. 1993. Historical Change in Serial Verb Constructions. Amsterdam \& Philadelphia: John Benjamins.

Haspelmath, M. 2016. "The serial verb construction: comparative concept and crosslinguistic generalizations”. Language and Linguistics 17(3), 291-319.

Roeper, T. 1993. "Explicit syntax in the lexicon: The representation of nominalizations". In Semantics and the Lexicon, edited by James Pustejovsky, 185-220. Dordrecht: Kluwer.

Sadock, J. 1991. Autolexical syntax. Chicago: University of Chicago Press.

Stewart, O. T. 2001. The Serial Verb Construction Parameter. New York: Garland. 